\title{
Bíos, alebo cultus? Nemecký rasizmus prvej polovice 20. storočia optikou vied o kultúre
}

\section{Bíos or Cultus? German Racism as seen through the Perspective of Cultural Science}

Miloslav Szabó

\begin{abstract}
The ideology of modern racism grew out of the 19th century political and economical crisis, as the newly emergent hierarchization of European societies depended upon earlier anthropological classifications and systems of colonialism. The decline of liberalism in the late 19th century confirmed this ideology, with its supposed impossibility of racial assimilation. In Germany, where racial boundaries were aligned with nationalism and antimodernism, a specific "religious" racism developed, one that defined "racial" distinctions largely in cultural rather than phenotypic terms. This was a tendency elaborated by thinkers such as Houston Stewart Chamberlain who in the interwar years inspired Nazi ideology and the so-called "racial psychology." Chamberlain was also central for many critical analyses of modern racism, an overlap that hints at the diffusion of science and "mythology" into modern racial ideology.
\end{abstract}

KEY WORDS antisemitism, ethnic religion, Germany, nationalism, Nazi ideology, racial psychology, racism

Ideológia moderného rasizmu je konglomerátom myšlienok a teorém, ktorých spoločného menovatel'a predstavuje úsilie legitimizovat' mocenské stratégie reprezentantov etablovaných spoločenských formácií. Rasizmus 19. storočia vystupoval v pozitivistickom duchu, čo sa prejavovalo najmä snahami aplikovat' exaktnost' a objektivizmus prírodných vied aj na sféru l'udskej spoločnosti, ktorej tradičné, hierarchické usporiadanie sa od čias Francúzskej revolúcie otriasalo v základoch. Úlohou rasistických utópií 19. storočia bolo reorganizovat' sociálny „chaos“ opätovnou hierarchizáciou spoločnosti, obnovením pseudovedecky legitimizovaného, hierarchizovaného poriadku podl'a vzoru európskych kolónií, kde sa ho „materským“ krajinám darilo udržiavat', ba tieto v 19. storočí ho ešte rozšírili a upevnili. Rasizmus vychádza z údajne nemenných psycho-somatických rozdielov medzi vel'kými skupinami l'udí (,rasami“), a principiálne odmieta možnost' ich „miešania“, teda asimilácie. Táto vo svojej najhlbšej podstate neokonzervatívna intencia predstavuje kvintesenciu rasistickej (či „,racialistickej“) ideológie. ${ }^{1}$

Sociální studia. Fakulta sociálních studií Masarykovy univerzity, 4/2007. S. 81-92. ISSN 1214-813X.

1 Väčšina definícií moderného rasizmu zdôrazňuje prvok hierarchie l'udských rás, a pritom akoby zabúdala na problém ich údajnej nezlučitel’nosti - „neasimilovatel’nosti“ (Banton a Miles 1996, Frederickson 2003). Napríklad antropológ Ivo Budil v polemike s tzv. „kontrarevolučnou“ interpretáciou rasizmu odopiera Arthurovi de Gobineauovi zaužívaný titul „,zakladatel'a“ moderného 
Hoci rasistickí ideológovia 19. storočia vychádzali z klasifikácie l’udských rás formulovaných v 18. storočí, ich zámerom bola stratifikácia a hierarchizácia európskych spoločností, „ohrozovaných“ rovnostárskymi požiadavkami liberalizmu, socializmu a demokratického nacionalizmu. Antiliberalistické tendencie sa však neobmedzovali iba na reprezentantov ancien régime a od začiatku 19. storočia ovplyvňovali romantické koncepcie stredoeurópskych meštianskych i aristokratických nacionalistov, ktorí sa prostredníctvom vágneho, ale univerzálne znejúceho pojmu „rasa“ (prípadne „plemeno“) usilovali obhájit’ svoje partikularistické nároky. Posun od demokratického k romantickému nacionalizmu, ktorý bol markantný najmä v nemeckom jazykovom prostredí, sprevádzala ideologická reštrukturalizácia, ktorej dôsledkom bola osobitá nacionalistická ideológia, spájajúca v sebe prvky rasizmu, nemeckého idealizmu, romantickej filozofie prírody, antisemitizmu a sekularizovaného náboženstva. Epocha reštaurácie nasledujúca po Viedenskom kongrese (1815), respektíve po revolučných rokoch 1848/49, ale predovšetkým postupný úpadok liberalizmu po zjednotení Nemecka roku 1870 túto ideologickú zmes pravidelne oživovali a prehlbovali. Rozmach sociálneho darvinizmu na konci 19. storočia jej napokon dodal charakteristický, agresívny nádych.

Vo svojej štúdii sa budem zaoberat’ ideológiou nemeckého rasizmu na príklade myšlienok Houstona Stewarta Chamberlaina, jedného z jej najvýznamnejších systematikov. Pokúsim sa rozlíšit' jednotlivé ideologické roviny jeho knihy Die Grundlagen des 19. Jahrhunderts (Základy 19. storočia, 1899) a definovat' ich vzt'ah k rasovej teórii, ktorá je, nazdávam sa, ich spoločným menovatel'om. Chamberlainov rasizmus bol súhrnom vyššie uvedených ideologických ingrediencií romantického nacionalizmu 19. a prvej polovice 20. storočia. Chamberlain sa nezaujímal iba o somatickú (,telo“), ale aj o psychickú konštitúciu l’udských rás („,duša“), ba dá sa povedat’, že psychickým a kultúrnym momentom venoval vo svojej knihe ovel'a väčší priestor než empiricko-somatickým analýzam. Napriek tomuto „kulturalistickému“ prístupu však zotrval na základných premisách rasistickej ideológie, zdôrazňujúc nerovnost' l’udských rás a odmietajúc ich miešanie. Chamberlainov kulturalistický rasizmus však nebol iba výrazom intelektuálnej krízy končiaceho sa 19. storočia, ktorá sa prejavovala medzi iným príklonom k „osvedčeným“ iracionalistickým koncepciám a ktorej sa nevyhol ani vedecky sa tváriaci dobový rasizmus. Kultúrne, a najmä náboženské zdroje boli jedným z jeho základných legitimačných prostriedkov. Vo svojej štúdii chcem preto poukázat' na skutočnost', že aj nemeckí rasisti - podobne ako hlásatelia etnickej exkluzivity vo všeobecnosti (Prentiss 2003) - podliehali mytologizácii.

Ak chceme porozumiet' Chamberlainovmu kulturalistickému rasizmu, musíme ho analyzovat' nástrojmi a metódami tzv. vied o kultúre. V nasledujúcom výklade teda nepôjde

rasizmu a rezervuje ho pre jeho krajana, saintsimonistu Victora Courteta. Courtet síce vychádzal z existencie rozdielnych l’udských rás, no na rozdiel od Gobineaua a jeho nástupcov (ale i predchodcov, napríklad Edwarda Longa) hlásal potrebu ich asimilácie (Budil 2005: 27). Jedným zo zásadných kritérí ideológie moderného rasizmu je však práve otázka asimilácie, jej akceptovanie respektive odmietanie. V tomto zmysle bol bezpochyby rasistom hlásatel' neasimilovatel'nosti l’udských rás Gobineau, ale sotva vyslovený stúpenec asimilácie Courtet. Mimochodom, naznačuje to aj pôvodný kontext pojmu ,asimilácia“, ktorý v období Francúzskej revolúcie vyjadroval požiadavku zrovnoprávnenia kolónií. 
o tradičnú kritiku ideológií - či už v pozitivistickom alebo marxistickom zmysle -, ale o rekonštrukciu a interpretáciu istého diskurzu, ktorý sa neobmedzoval iba na reprezentantov „akademických“ rasových teórií. Tento prístup predstavuje voči tradičným koncepciám dejín ideí zásadný posun, pretože pomáha osvetlit’ skryté mechanizmy produkcie, a hlavne reprodukcie na prvý pohl'ad výlučne scientistických ideologických konštrukcií. Medzi kultúrne javy - kultúrou nazývam v tomto prípade tvorbu, to znamená šírenie a osvojovanie si ,zmyslu“ (Conrad a Kessel 1998: 10) - zahŕňam „obsahy“ tradičných i moderných identifikačných mechanizmov, $\mathrm{v}$ danom prípade predovšetkým politizovaných náboženských synkretizmov a „svetonázorov“ 19. storočia.

V prvom kroku budem interpretovat' Chamberlainovu rasovú teóriu, ktorú považujem za východiskový bod nábožensko-rasistického diskurzu prvej tretiny 20. storočia. Poukážem jednak na Chamberlainov príspevok k rozvoju ,,akademickej“ rasovej teórie, no najmä na jeho pokus legitimizovat' vlastnú ideologickú konštrukciu kultúrnymi motívmi. Vychádzam pri tom z tézy, že kulturalizmus a etnicko-náboženský synkretizmus pomohli rozšírit' nemecký rasizmus v ovel’a väčšej miere, než by to dokázali elitárske „akademické“ koncepcie.

V d'alšom kroku sa zameriam na ideologický vplyv Chamberlainovej teórie na generáciu nemecky píšucich rasistov, respektíve kritikov rasizmu, ktorých pôsobenie spadá do medzivojnového obdobia. Hned' na začiatku by som rád zdôraznil, že mojím zámerom nie je vyčerpávajúca rekonštrukcia vplyvu náboženského rasizmu na súčasníkov; nebudem sa v tomto zmysle zaoberat' ani ideologickou praxou, to znamená mechanizmami ideologickej indoktrinácie. Zameriam sa výlučne na diskurzívne momenty, ktoré možno pokladat’ za paradigmatické pre proces legitimácie ideológie extrémneho rasizmu vo vyššie uvedenom zmysle odmietania asimilácie odlišných ,rás“, a síce na príklade koncepcií Alfreda Rosenberga, Ludwiga Ferdinanda Claussa a Ericha Voegelina.

\section{Houston Stewart Chamberlain}

Rozsiahlejšia recepcia knihy Essay sur l'inegalité des races humaines (Esej o nerovnosti l'udských rás, 1855) z pera ,zakladatel'a“" moderného rasizmu Arthura de Gobineaua korešpondovala v Nemecku s nástupom darvinizmu v osemdesiatych a devät'desiatych rokoch 19. storočia. Zásluhu na popularizácii Gobineauovej teórie mal predovšetkým okruh stúpencov Richarda Wagnera, medzi ktorých patril aj jeho neskorší zat' Houston Stewart Chamberlain (1855-1927). Chamberlain, ktorý sa narodil v Anglicku, vyrastal vo Francúzsku, študoval prírodné vedy vo Švajčiarsku a žil dlhé roky vo Viedni, publikoval roku 1899 dvojzväzkový opus magnum Základy 19. storočia (Field 1981). Chamberlain, hlásiaci sa k nemeckej kultúre, tu načrtáva univerzálne dejiny európskej civilizácie, ktorá je podl’a neho „germánsko-keltsko-slovanským" výtvorom.

Pät’ zákonov „,vzniku vznešených rás“, ktorými Chamberlain reagoval na Gobineauovu pesimistickú prognózu všeobecného rasového úpadku, údajného výsledku miešania rás, prezrádza silný vplyv darvinizmu. Najdôležitejším predpokladom je „vynikajúci materiál“, z ktorého treba presne cielenými, časovo ohraničenými krokmi ,vyšl'achtit"“ novú rasu (Chamberlain 1899, 1: 277-285). Posun voči Gobineuaovi je obrovský, umožňuje totiž špekulácie o revitalizácii „starnúcich“ rás. Chamberlain vskutku prevracia Gobineauove predstavy 
naruby: „Normálny, zdravý vývin l'udstva neprebieha od rasovosti k bezrasovosti, ale práve naopak: od bezrasovosti k čoraz výraznejšie charakteristickej rase..." (Chamberlain 1899, 1: 293). Rasa je „organická, živá bytost“", je neustále v pohybe. Chamberlain preto reformuluje vzt’ah medzi rasou a národnou individualitou. Až národné spoločenstvo vytvára podmienky pre konštitúciu rasy.

Chamberlain sa však nechcel zmierit' so scientistickým vysvetlením „vzniku vznešených rás“. Nezat’ažoval sa príliš (prírodo)vedeckou exaktnost’ou, a spoliehal sa väčšmi na vlastnú intuíciu. Hlavnou charakteristikou l'udských rás podl'a neho nemusel byt' charakteristický a nemenný fenotyp, ale isté „duchovné" kvality, manifestujúce sa v umení, vo filozofii, a predovšetkým v náboženstve.

Náboženstvo, presnejšie sekularizované krest’anstvo, patrilo od začiatku 19. storočia medzi hlavné legitimačné zdroje nemeckého nacionalizmu. Táto skutočnost' sa týka najmä koncepcie spoločnosti ako „telesnej idey“, vychádzajúcej zo stredovekého chápania cirkvi ako Kristovho tela či corpus mysticum. Už v ranom novoveku dochádzalo k sekularizácii „mystického tela“, jej podoby sa však v jednotlivých protonárodných spoločenstvách značne líšili (Kantorowicz 1990). V politicky rozdrobenom Nemecku, ktoré sa národne „prebudi10 “ až počas protifrancúzskeho povstania začiatkom 19. storočia, sa tieto predstavy prelínali s Fichteho pseudokrest’ansky zdôvodňovanou náukou o „,vyvolenosti““ Nemcov, ktorí sa údajne priamo podiel'ajú na božej transcendencii (Brumlik 2000: 107-122).

Pre účely predkladanej štúdie je rozhodujúci fakt, že v priebehu sekularizácie sa spochybnila psycho-somatická komplementárnost', príznačná pre koncepciu corpus mysticum, a jej miesto zaujala romantická „,rozorvanost“", nesúlad tela a duše, zdôrazňujúci negatívne aspekty romantického chápania prírody a l'udskej telesnosti - pudovost' a mechanicizmus. ${ }^{2}$ Ak matéria, kedysi posväcovaná „duchom svätým“, nemá ustrnút' v negativizme, vyžaduje si opätovnú sakralizáciu - túžba po ,jednote tela a duše“ sa však presúva z oblasti náboženstva do sféry sekularizovaných politických inštitúcií moderného národného štátu. Zatial' čo stredovekí teológovia definovali cirkev analogicky s jednotou božského a l'udského v „Kristovom tele“, ideológovia nemeckého nacionalizmu a rasizmu postulovali jednotu národného/rasového tela a duše (Volksgeist/Rassenseele) a jej narušenie zdôvodňovali - prinajmenšom posledne menovaní - „nevhodným“ miešaním rás.

Chamberlain celkom v duchu romantickej filozofie prírody odmieta jej abstraktné, mechanistické chápanie a nahrádza ho „celostnými“ koncepciami. Princíp „mechanizmu“ myslí sa tým aj biologizmus - podl'a neho neponúka uspokojivé vysvetlenie prírody, pretože človek, súčast' prírody, v sebe pocit'uje „božský princíp“, ktorý projektuje navonok, čím mení povahu sveta i prírody (Chamberlain 1899, 2: 913-937). Skutočnost', že Chamberlain sa vzdal racionalizmu prírodných vied $\mathrm{v}$ prospech romantického mysticizmu, mala závažné dôsledky pre jeho rasovú teóriu. „Čistá“ rasa predstavuje ,jednotu tela a duše“ (Gestalt) a chráni jednotlivca súčasne pred hrozbami archaickej pudovosti i moderných abstrakcií, ktoré redukujú prírodu na jeden z jej aspektov. Chamberlain síce nezavrhuje miešanie rás ako také, ale zásadným spôsobom ho obmedzuje - isté „zmesi“ navyše vôbec neprichádzajú do úvahy. Iba rasovo „čistí“ jedinci dokážu súčasne nadviazat' kontakt s absolútnom a „zušl'acht’ovat““

2 O romantickom pojme prírody pozri Marquard (1987). 
vlastnú telesnost' - na rozdiel od potomkov stredomorského a blízkovýchodného „rasového chaosu“, v ktorých telesnost' potláča všetky duševné kvality. Typickými predstavitel'mi rasovo zmiešaných „bastardov“ boli podl’a Chamberlaina katolícka cirkev a Židia.

Ideológovia rasizmu hierarchizujú národný kolektív a vylučujú z neho vonkajších i vnútorných „nepriatel’ov“. Chamberlain svoj politický program zúžil na etnické náboženstvo, ktoré mu splývalo s rasizmom. ${ }^{3}$ Tento moment sa zretel'ne prejavuje v posudzovaní náboženstva $a$ „rasy“ starých Izraelitov, kde bios a cultus údajne tvorili nerozlučnú jednotu. Na rozdiel od Benjamina Disraeliho, ktorý pomáhal v 19. storočí šírit’ predstavu „Židovskej rasy“4, sa však antisemita Chamberlain usiloval uzurpovat’ toto „cenné dedičstvo“ pre Germánov či „Árijcov“. Židia sa podl’a neho prehrešili proti zákonom „vzniku vznešených rás“, pretože proroci pomiešali „,morálne a fyzicky odlišné typy“ (Chamberlain 1899, 1: 346). Výsledkom týchto procesov vraj bola charakteristická individualita „Žida“, ktorej dominujú túžba po svetovláde, hrubý materializmus a egoizmus.

Pri charakteristike antropologických typov „Germána“ a „Žida“ Chamberlain vychádzal zo zvulgarizovanej dilemy nemeckej idealistickej filozofie 19. storočia. Komplementárnost’ oboch typov je nadmieru očividná a zodpovedá Chamberlainovmu ambivalentnému chápaniu prírody, ktoré som načrtol vyššie a ktoré je základom jeho rasovej teórie. Najdôležitejším atribútom nemeckého i židovského charakteru je podl'a neho vôl'a (hoci kantovec Chamberlain zdôrazňoval individualizmus, tento princíp sa zvrhol na oslavu individualizovaného kolektívu). No zatial’ čo u Germánov si udržala idealistické konotácie a pomáhala im zachovat' morálnu integritu, takže mohli projektovat' svoje „božské vnútro“ do okolitého sveta a „stvárňovat"“ (gestalten) vlastnú rasu, u Židov sa zvrhla na Schopenhauerov deštruktívny princíp ničím nekontrolovaného pudu, ktorý predstavuje hrozbu pre všetko „duchovné“. Tento protiklad mal vysvetl'ovat', prečo sa etnické náboženstvo $v$ jednom prípade prejavuje pozitívne, v druhom negatívne: Zatial' čo Germánom „duša“ pomáha pestovat' rasu, nemajú Židia na podobné atribúty nárok, naopak, musia pykat' za svoj „dedičný hriech“ - „nevhodné“ rasové miešanie.

3 Protestant Chamberlain sa síce nadchýňa krest'anstvom, nemá však, pochopitel'ne, na mysli inštitucionalizovanú cirkev, ale náuku o „vnútornom obráteni““, ktoré individualizovanému kolektívu údajne pomáha získat' bezprostredný kontakt s absolútnom. Chamberlain navyše podmieňuje toto „nemecké“ krest’anstvo rasistickou ideológiou. Vyhlasuje Krista za „Árijca“, ktorý údajne hlásal heroickú morálku: „Ak nastavujem bezočivému bitkárovi líce, nerobím to kvôli nemu; ak milujem svojho nepriatel'a a preukazujem mu dobré skutky, nerobím to kvôli nemu. Po obrátení vôle inak nemôžem, preto to robím. Starý zákon: oko za oko, zub za zub predstavuje rovnako prirodzený reflex ako ten, ktorý sa prejavuje pri podráždení nervov už nejaký čas mítvej žaby“ (Chamberlain 1899, 1: 205-206). „Arizáciou“ krest’anstva v Nemecku v 19. a na začiatku 20. storočia sa zaoberá Fenske (2005).

4 Glasman (2003) poukazuje na skutočnost', že Disraeliho predstavy vychádzali z domácich, britských zdrojov. 


\section{Recepcia Chamberlainovej rasovej teórie v medzivojnovom Nemecku}

Houston Stewart Chamberlain sa v priebehu prvých desat'ročí 20. storočia stal „klasikom“ vzdelaných i menej vzdelaných meštianskych vrstiev v celej Európe. ${ }^{5}$ Najväčší vplyv však mal, pochopitel'ne, v nemeckej jazykovej oblasti. Predstava, že národ je výsledkom „vhodného“ rasového miešania, ovplyvnila nové klasifikácie rás v medzivojnovom období. Je príznačné, že tieto klasifikácie sa v Nemecku, ktoré malo relatívne málo skúseností s kolonializmom, týkali predovšetkým európskych a - vzhl'adom na paradigmu odlišnosti, ktorú v Nemecku stelesňovali pôvodne nábožensky stereotypizovaní Židia - blízkovýchodných populácií. „Árijský mýtus“, ktorý sa v Európe udomácňoval od konca 18. storočia a ktorý bol výrazom znovuoživených západných fantázií o Oriente, v medzivojnovom období ustupoval novším teóriám o „nordickej“ rase. ${ }^{6}$ Súčasne s nimi sa naplno rozvinul charakteristicky nemecký variant orientalizmu, ktorý zjednotil predstavy o odlišnosti, zahŕňajúce predovšetkým blízkovýchodných „Semitov“.

\subsection{Alfred Rosenberg}

Ideológ nacistickej strany NSDAP Alfred Rosenberg (1893-1946) rozpracoval Chamberlainov „,kulturalistický“ a náboženský rasizmus v knihe Der Mythus des 20. Jahrhunderts (Mýtus 20. storočia, 1930), ktorej radikalizmus výrazne prevyšuje svojho predchodcu. Rosenberg v podstate prevzal Chamberlainovu argumentáciu a aplikoval ju na situáciu v Nemecku po prvej svetovej vojne. Odstránil zvyšky Chamberlainovej liberálnej a krest’anskej rétoriky v prospech „,náboženstva krvi“, ktorého „teológiu“ vcelku dôsledne odvodzoval z Fichteho filozofie náboženstva. „Neskazená“ krv dodáva svojmu nositel'ovi takmer telepatické schopnosti a umožňuje mu bezprostredný kontak s transcendentnom. ${ }^{7}$

Rosenberg sa prakticky nevenuje opisu rasových fenotypov - tieto sú redukované na naivné estetické protiklady svetlý/tmavý, štíhly/územčistý atd'. - a namiesto nich si všíma umelecké nadanie, mystické vlohy či predstavy o nesmrtel'nosti rasistického dualizmu „,nordický“/,semitský“, ktorý mu splýva s protikladom nemecký/židovský. Pokladá národ za konglomerát rozličných európskych rás, tieto však podliehajú „,rasovej dominante“, „nordickej krvi“. Tento „spojovací článok“ stvárňuje predovšetkým nemecký národ, ale aj jeho „menejcenné“ súčasti: „Nemecké je nordické a pôsobilo kultúrne a typotvorne aj na vestickú, dinársku a osticko-baltskú rasu“ (Rosenberg 1940: 576). „Nordická krv“ si žiada istý typ, ktorého základom je u „čistej“ rasy jednota tela a duše (Gestalt): „Táto rasa je však vonkajším obrazom duše, a duša vnútrajškom rasy“ (Rosenberg 1940: 529).

Inak je to v prípade „bastardizovaných“ rás, teda produktov „nevhodného“ miešania -nacistický ideológ pripúšt’a dokonca možnost' „duchovnej bastardizácie“, ku ktorej údaj-

5 Základy 19. storočia vyšli už pred prvou svetovou vojnou napríklad i v českom preklade a nadchýňali aj pacifistov ako bol L. N. Tolstoj.

6 Táto transformácia vychádzala z poznatkov vied o germánskom staroveku, ktoré situovali pravlast' Germánov do Škandinávie (See 1994). O ,árijskom mýte“ pozri Poliakov (1977).

7 O Fichteho protižidovsky motivovanej náboženskej filozofii pozri Brumlik (2000: 75-131). 
ne dochádza bez fyzického kontaktu ${ }^{8}$-, ktoré nemajú nijakú dušu. Topos bastardizácie (Rassenschande) a jej následkov sa týka najmä historických partií Rosenbergovej knihy, predovšetkým opisov stredomorského antického sveta. Zánik starovekých kultúr odvodzuje zo „Zmiešaného rasového manželstva“, ktoré podkopalo základy patriarchálnych rasových kultúr starého Grécka a Ríma. Paradigmou bastardizácie je však ,židovská antirasa“, ktorá nemá umelecké vlohy, neverí v nesmrtel’nost' duše a jej jediným ciel'om je svetovláda a „rozklad“ rasových štátov budúcnosti - na čele s „nordickým“ Nemeckom. Obrana pred bastardizáciou preto predstavuje jednu z nadchádzajúcich úloh nemeckej politiky. ${ }^{9}$

\subsection{Ludwig Ferdinand Clauss}

Nové rasové klasifikácie, na ktoré sa odvolával Alfred Rosenberg, v medzivojnovom Nemecku popularizovali najmä antropológ Hans Friedrich Karl Günther, ktorému sa však vzhl'adom na tému štúdie nebudem venovat', a Ludwig Ferdinand Clauss (1892-1974), zakladatel' nového odboru „rasovej psychológie“. Clauss bol žiakom filozofa Edmunda Husserla a hlásatel'om rasistického variantu psycho-somatického paralelizmu, známeho pod názvom „fyzignomika“ (Schmölders a Gilman 2000). Vo svojich početných spisoch sa venoval predovšetkým telesnému výrazu „rasovej duše“, pre ktorý používal „mysticky“ znejúce nemecké pojmy Gestalt (jednota tela a duše) a Leib (,zduchovnené“ telo). Spočiatku dost’ konvenčne oslavoval heroizmus „,nordickej rasy“, neskôr s fotoaparátom v ruke precestoval Blízky Východ, kde v prestrojení za „nemeckého šejka“ skúmal takzvanú „púštnu (orientálnu)“ a „blízkovýchodnú (armenoidnú)“ rasu. V tridsiatych rokoch získal katedru na Berlínskej univerzite, počas druhej svetovej vojny však upadol do nemilosti nacistického režimu, zakázali mu publikovat' a vylúčili ho zo strany. Bol dokonca upodozrievaný z „,prehrešku proti krvi“ (Rassenschande), teda zo sexuálnych kontaktov so svojou židovskou asistentkou, ktorú ukrýval do konca vojny pred prenasledovaním (Weingart 1995).

Clauss bol zástancom takzvanej „mimickej metódy“, pomocou ktorej sa intuitívne vcit’oval do „ideí-stvárneni““ (Gestalt-Ideen) konkrétnych l’udí. Bol presvedčený, podobne ako Chamberlain, o jednote duše a tela, ktorú označoval rovnakým pojmom Gestalt. Jeho „rasová psychológia“" sa netýkala iba tela (Leib), ale aj, ba najmä duše: „Telo sa tu teda nahliada ,zvnútra“ a je chápané ako niečo, čoho tvar je podmieňovaný tvarom duše“ (Clauss 1933: 117). Claussa zaujímalo vnútorné „prežívanie“, prejavujúce sa mimikou. Duša zasahuje do okolitého sveta a, podobne ako u Chamberlaina, stvárňuje ho - a spolu s ním aj vlastné telo. „Ked’ dve duše napíña rovnaký štýl prežívania a ked’ pristupujú k svetu s rovnakou mimikou, hovoríme, že majú rovnaký povahový ráz a rovnakú rasu“ (Clauss 1939: 16). Clauss možno nebol fanatickým rasovým ideológom, no napriek tomu požadoval, aby „duša s istým štýlom prežívania“ mala zodpovedajúce „telesné javisko“: „Štýl tela a jeho výrazových prostried-

8 Tento topos sa objavuje napríklad už v rasisitickom a sexistickom spise Otta Weiningera Geschlecht und Charakter (Pohlavie a charakter, 1902), ktorý takisto vychádzal z Chamberlainovej rasovej teórie.

9 Rosenberg mal na rozdiel od väčšiny iných „teoretikov“ nemeckého rasizmu možnost' realizovat' svoje predstavy aj politicky, pravda, s malým úspechom (Piper 2005). 
kov musí byt' totožný s výrazovým štýlom a prežívaním duše“ (Clauss 1933: 135). Inými slovami, nie každá duša je vhodná pre konkrétne telo - v takýchto prípadoch Clauss hovorí o „zlomenom výraze“, ktorý chce liečit’ „psychológiou rasovo zmiešaných štýlov“. Takýto štýl človek dostáva do vienka, na rozdiel od výrazu, ktorý získava v prostredí, kde žije. Hlavným problémom Claussovej terapie je otázka, ako zosúladit' prevládajúci „,výraz prežívania“ so zodpovedajúcim „rasovým štýlom“. Skutočnost', že Clauss nerezignoval na hlavnú premisu rasistickej ideológie, nezlučitel'nost' niektorých l'udských rás, potvrdzuje poznámka, že nie každý výraz je vhodný pre „l'ubovol’ne zmiešané rasy“ (Clauss 1933: 156).

L’udské rasy totiž nie sú ani u tohto netradičného, ,idealistického“ rasistu rovnocenné. Dokonca ani Germáni nemajú rovnaké rasové zloženie. Ich kultúru a tvorivost' „rasovo podmieňuje spojenie nordického a fálskeho štýlu“, ktorý takpovediac „,uzemňuje“ nordický idealizmus (Clauss 1939: 62). To však neznamená, že Germáni (teda predovšetkým Nemci) smú pokračovat' $\mathrm{v}$ asimilácii donekonečna. Chamberlainove rasové zákony pôsobia aj u Claussa ako akési memento: V prípade, že sa Germáni nebudú bránit' prieniku cudzích prvkov, ich Gestalt sa rozpadne a jej jednotlivé čiastky si prestanú rozumiet'. Clauss vidí úlohu svojej „rasovej psychológie“ medzi iným v odkrývaní hraníc, „ktoré nijaký národ, nijaké pokrvné a kultúrne spoločenstvo nesmie prekročit', ak sa nechce samo zničit“" (Clauss 1939: 63).

Vplyv náboženských predsudkov na Claussov variant rasizmu sa mimoriadne plasticky prejavuje v jeho opise blízkovýchodných rás. Zatial' čo „výkonný človek“ severnej Európy údajne žije v harmónii s vlastným telom, „,̌lovek zjavenia“ a „,vykupitel’ský človek“ Blízkeho Východu stelesňujú rozorvanost', ktorú Clauss inak diagnostikuje iba u „rasovo zmiešaných štýlov“. Videli sme, že Chamberlain stotožňoval antropológiu Židov a "Semitov“ so Schopenhauerovou vôl'ou-pudom; Clauss sa snaží túto „anomáliu“ odvodit' z monoteizmu. Nezvládnutá pudovost' je - podobne ako v prípade Nietzscheho kritiky náboženstva - daň za jednostrannú askézu, ktorá v podmienkach asimilácie údajne zvykne zmenit’ náboj: „Všetky hodnoty, od ktorých odpadli, obrátia v pravý opak: Namiesto posväcovania znesväcujú, namiesto prekonania tela zavádzajú jeho kult, namiesto zduchovnenia prepadajú materializmu..." (Clauss 1933: 98). Po všetkom, čo sme uviedli v predchádzajúcich odsekoch, je zrejmé, o kom je reč. Clauss však pre istotu upresňuje: Na Západe sa to týka tamojších Židov. ${ }^{10}$

\subsection{Erich Voegelin}

Jeden z prvých pokusov o teoretickú analýzu západného, a zvlášt’ nemeckého, rasizmu predstavuje štúdia katolíckeho filozofa Ericha Voegelina (1901-1985) Rasse und Staat (Rasa a štát, 1933). Voegelin, ktorý neskôr emigroval do USA, kde vytvoril monumentálne dielo Order and History (Poriadok a dejiny, 1956-1987), pristupoval vo svojej ranej práci $\mathrm{k}$ problematike rasizmu spôsobom, ktorý stál až donedávna na okraji vedeckého záujmu. Voegelinom inšpirovaná „náboženská politológia“ nám dnes opät' umožňuje tematizovat' javy, ktoré sa týkajú kultúrnych vplyvov na vývin rasových teórií. Metóda a premisy tejto „náboženskej politológie“ však súčasne potvrdzujú jej previazanost's predmetom výskumu -

10 Vzt'ah k spomínanej židovskej asistentke patrí do iného kontextu - podobne ako skutočnost', že Clauss konvertoval po druhej svetovej vojne na islam. 
v tomto prípade s dejinami „kulturalistického“ rasizmu, ktoré sme sledovali na príklade niektorých jeho prominentných predstavitel'ov.

Voegelin v prvom rade striktne rozlišuje medzi „materialistickým“, teda prírodovedecky sa tváriacim rasizmom a rasizmom niektorých nemeckých autorov, ktorí podl'a neho zohl'adňovali „,ducha a dušu“. Napríklad o „náboženstve krvi“ Alfreda Rosenberga sa u Voegelina dočítame: „Hovorí sa tu o zážitku ,súladu tela, duše a ducha', ktorý je ,symbolizovaný‘ vo vedomí ,krvi‘. Samo politické hnutie [NSDAP, M. S.] rozvíja ideu jednoty človeka ako celistvej bytosti, ktorú starší teoretici rasy stále rozhodne odmietajú. Pripadá mi ako potešujúce znamenie, že prekonané zvyšky darvinistickej teórie časom miznú aj z teórie o rasách“ (Voegelin 1933: 15-16). Vzhl'adom na závislost' nacistického ideológa na Chamberlainovej, darvinizmom inšpirovanej rasovej teórii ide vskutku o dost' nečakané konštatovanie. No práve problematika ,jednoty tela a duše“ predstavuje najdôležitejší moment, ktorý spájal katolíka Voegelina so sekularizovanými protestantmi Chamberlainom a Rosenbergom. Toto dnes už málo zrozumitel'né heslo totiž signalizuje polemiku s moderným materializmom a racionalizmom, ktorá sa odohráva na poli prírodovedecky sa tváriacich rasových teórií.

Voegelin polemizuje vo svoje štúdii i s dobovou filozofickou antropológiou, ktorej reprezentanti (napríklad Max Scheler) údajne stále neprekonali „,rozpoltenost““ moderného človeka na duchovnú a telesnú sféru. Riešenie v podobe teórie „sublimácie“ raného Voegelina neuspokojuje - akiste aj kvôli jej psychoanalytickým konotáciám. Oslovuje ho skôr „rasová psychológia“ L. F. Claussa, konkrétne jeho koncepcia psycho-somatického paralelizmu: „Duch [...] sa neusadzuje v matérii ako niečo nemenitel’né, ale vytvára sa v procese tvorby vlastného tela [...]. Spôsob, akým sa prejavuje v tele, je viditel'ne stvárňovaný duchovnými kvalitami fyziognómie a mimikou“ (Voegelin 1933: 33). Ukázali sme, že práve podobné predstavy sprevádzali - spolu s darvinizmom - Chamberlainovo úsilie reformulovat' pesimistickú Gobineauovu rasovú teóriu v zmysle „šlachtenia“/,stvárňovania“ nových rás. Voegelin tieto komplikované súvislosti medzi darvinizmom a sekularizáciou tradičných ekleziologických predstáv asi nevidel. Aj preto komentuje uvedený posun nasledujúcimi slovami: ,„...] Gobineauov pesimizmus teoreticky podmieňuje predpoklad rasy ako nemenitel'ného prírodného javu a všetky neskoršie materialistické [!] rasové teórie obsahujú rovnaký prvok fatalizmu“"(Voegelin 1933: 178 [poz.]).

Rozhodujúce však je, že Voegelin si vôbec nevšíma skutočnost', že všetci ním uprednostňovaní „kulturalistickí“ rasisti hlásali zásadnú nemožnost' rasovej asimilácie (odhliadnuc od „vhodného“ a krátkodobého miešania rás v duchu Chamberlainových zákonov). Rovnako neberie na vedomie, že dokonca ani Clauss nebol ochotný uznat' rovnocennost' ludských rás, nehovoriac o možnosti ich bezpodmienečnej asimilácie. Boj proti „materializmu“ zaslepil raného Voegelina natol'ko, že prehliadol „sebazbožňujúce“ tendencie synkretických náboženských prúdov konca 19. a prvej polovice 20. storočia, medzi ktoré sa zarad'ujú aj vyššie analyzované rasové teórie. ${ }^{11}$

11 To je azda jedna z príčin, prečo sa Voegelin k svojmu ranému dielu vel'mi nehlásil. Práve spomínané tendencie „sebazbožnenia“ povýšil neskôr na univerzálny princíp „gnostickej vzbury“ proti tradičným formám spoločenského usporiadania (Voegelin 2000). 
V našich súvislostiach je príznačný taktiež fakt, že Voegelinovi spôsobovala problémy pseudonáboženská legitimácia antisemitizmu u Chamberlaina a jeho nástupcov. ${ }^{12}$ Voegelin sa vyhýba odpovedi na otázku, prečo sú objektom nenávisti nemeckých rasistov práve Židia: „Národy [!] sú neredukovatel’né jednotky dejín a otázku, prečo sú niektoré z nich duševne spriaznené a iné sa nenávidia, si asi nesmieme klást"“ (Voegelin 1933: 182). Voegelin však napriek tomu špekuluje o dôvodoch protižidovskej nenávisti, opierajúc sa o antisemitské klišé ekonomického „vykoristovania“ a údajného etnického vymedzovania zo strany Židov, pričom nerozlišuje medzi asimilantmi a sionistami. Nenávist' voči nim vyplýva podla neho jednak zo skúsenosti „,bezprostredného osobného hospodárskeho poškodzovania Židmi“ a jednak z , dejinnej skutočnosti... že oni sami sú partikulárnym spoločenstvom [s univerzalistickými nárokmi, M. S.], možno najintenzívnejším v celých dejinách, že celé zvyšné l’udstvo pokladajú za protivníka“ a že tento nárok hlásajú ,s niekedy až nepravdepodobnou naivitou“ (Voegelin 1933: 186). Etnicitu údajne dokáže oslabit' iba krest’anstvo a paradigmatickým príkladom tohto procesu bolo krest’anské „,prekonanie“ judaizmu. Inými slovami, Voegelin kladie vel'ký podiel viny na vzniku a rozšrirení antisemitizmu samým Židom. Je príznačné, že vo svojich neskorších dielach sa už k problematike antisemitizmu nevyjadroval.

\section{Záver}

Na záver je potrebné zaradit' analyzované rasové koncepcie do širších súvislostí. Rasisti sa, podobne ako iní ideológovia, usilovali a usilujú dodat' svojim myšlienkam aureolu ,večných“, či aspoň nemenitel’ných právd. Je preto pochopitel'né, že využívajú aj iné než vedecké legitimačné stratégie. Atmosféra v Európe konca 19. a prvej polovice 20. storočia, charakterizovaná úpadkom liberalizmu a nárastom iracionalizmu, vytvorila vhodnú pôdu pre rozvoj ideologických alternatív, v ktorých rámci sa pohybovali aj zástancovia a hlásatelia synkretických pseudonáboženských prúdov $\mathrm{v}$ dobovom politickom myslení. Vplyvná čast' nemeckých rasových teoeretikov na čele s Houstonom Stewartom Chamberlainom sa ani netajila sklonmi k mytologizovaniu. Ideologický konglomerát - romantická filozofia prírody, sociálny darvinizmus, sekularizovaný protestantizmus a antisemitizmus -, ktorého syntézu Chamberlain ponúkal v knihe Základy 19. storočia, mal v krízami zmietanom medzivojnovom Nemecku vel'kú odozvu. Príklad nacistického ideológa Alfreda Rosenberga ukazuje, že náboženský rasizmus v Chamberlainovom duchu sa za istých okolností môže rozvinút' na dôsledný pokus o ideologickú kanonizáciu. Veda sa tu stáva nástrojom kulturalistickej mytológie. Prípad „rasového psychológa“ Ludwiga Ferdinanda Claussa je zaujímavý tým, že náboženské - či „duchovné“ - momenty majú uňho takpovediac dopĺn̆at’ vedecké nástroje a teorémy, „rozširovat"“ horizont vedy. No diskurz náboženského rasizmu bol v prvej polovici 20. storočia kontaminovaný ideológiou „nerovnosti rás“, ktorú - napriek niektorým náznakom - ani Clauss neodokázal celkom prekonat'. Útechou mu môže byt' skutočnost', že nebol sám: Katolícky politológ Erich Voegelin takisto podl’ahol zdaniu neideologickosti nábo-

12 Len na okraj poznamenávam, že antisemitizmus - hoci zväčša nie v rasistickej verzii - bol dôležitou súčast'ou ideológie moderného katolicizmu. 
ženského rasizmu. Jeho rozlišovanie medzi scientistickým a „duchovným“ rasizmom bolo poplatné diskurzívnej formácii, ktorú kritizoval.

\section{Liłeratúra}

Banton, M.; Miles, R. 1996. „Racism.“ In E. Cashmore (ed.). Dictionary of Race and Ethnic Relations. London/New York, s. 308-312.

Brumlik, M. 2000. Deutscher Geist und Judenhass. Das Verhältnis des philosophischen Idealismus zum Judentum. München.

Budil, I. T. 2005. „Historické proměny rasové teorie a ideologie.“ In I. T. Budil, V. Blažek, V. Sládek (ed.). Dějiny, rasa a kultura. Plzeň, s. 5-32.

Clauß, L. F. 1939. Die nordische Seele. Einführung in die Rassenseelenkunde. München/ Berlin.

Clauß, L. F. 1933. Rasse und Seele. Eine Einführung in den Sinn der leiblichen Gestalt. München.

Conrad, Ch.; Kessel, M. 1998. „Blickwechsel: Moderne, Kultur, Geschichte““ In Kultur \& Geschichte. Neue Einblicke in eine alte Beziehung. Stuttgart, s. 9-40.

Fenske, W. 2005. Wie Jesus zum Arier wurde. Auswirkungen der Entjudaisierung Christi im 19. und zu Beginn des 20. Jahrhunderts. Darmstadt.

Field, G. G. 1981. Evangelist of Race. The Germanic Vision of Houston Stewart Chamberlain. New York.

Frederickson, G. M. 2003. Rasismus. Stručná historie. Praha.

Glassman, B. 2003. Benjamin Disraeli. The Fabricated Jew in Myth and Memory. New York: Lanham.

Chamberlain, H. S. 1990. Die Grundlagen des 19. Jahrhunderts, 2 zv. München.

Kantorowicz, E. H. Die zwei Körper des Königs. Eine Studie zur politischen Theologie des Mittelalters. München.

Marquard, O. 1987. Transzendentaler Idealismus. Naturphilosophie. Psychoanalyse. Köln.

Piper, E. 2005. Alfred Rosenberg. Hitlers Chefideologe. München.

Poliakov, L. 1977. Der arische Mythos. Wien.

Prentiss, C. R. (ed.) 2003. Religion and the Creation of Race and Ethnicity. An Introduction. New York.

Rosenberg, A. 1940. Der Mythus des 20. Jahrhunderts. Eine Wertung der seelisch-geistigen Gestaltungskämpfe unserer Zeit. München.

See, von K. 1994. Barbar, Germane, Arier. Die Suche nach der Identität der Deutschen. Heidelberg.

Schmölders, C.; Gilman, S. L. (ed.) 2000. Gesichter der Weimarer Republik. Eine physiognomische Kulturgeschichte. Köln.

Voegelin, E. 1933. Rasse und Staat. Göttingen.

Voegelin, E. 2000. Nová véda o politice. Brno.

Weingart, P. 1995. Doppelleben. Ludwig Ferdinand Clauß. Zwischen Rassenforschung und Widerstand. Frankfurt a. M. 


\section{Autor}

Miloslav Szabó působí od roku 2007 v Centru pro výzkum antisemitismu na TU Berlin. Vystudoval historii a germanistiku na FiF UK v Bratislavě, doktorát (PhD.) získal na FSV UK v Praze. Odborně se věnuje především problematice nacionalismu, rasismu a antisemitismu.

Kontakt: mszabo@inmail.sk 